\title{
PENGARUH KONSENTRASI DAN LAMA PERENDAMAN A. pintoi DENGAN URIN TERNAK SAPI TERHADAP PERTUMBUHAN TANAMAN $A$. pinto $i$
}

\author{
Novalia Lumban Gaol*, Ch. L. Kaunang, Rustandi, F. Dompas \\ Fakultas Peternakan Universitas Sam Ratulangi Manado, 95115
}

\begin{abstract}
ABSTRAK
Urin sapi yang mengandung auksin a, auksin b, dan IAA (hetero auksin) dapat merangsang pertumbuhan akar tanaman. Penelitian ini dirancang untuk mengetahui pengaruh konsentrasi dan lama perendaman di dalam cairan urin sapi terhadap pertumbuhan Arachis pintoi (A. pintoi). Penelitian ini menggunakan Rancangan Acak Lengkap (RAL) pola faktorial dengan 2 faktor. Faktor $\mathrm{A}=$ konsentrasi urin: $\mathrm{A} 1$; urine $75 \%+\operatorname{air} 25 \%$; $\mathrm{A} 2$; urin $50 \%$ + air 50\%; dan faktor $\mathrm{B}=$ lama perendaman: $\mathrm{B} 1=1 \mathrm{jam} ; \mathrm{B} 2=2 \mathrm{jam}$; dan, B3 $=3 \mathrm{jam}$ perendaman). Perlakuan diulang sebanyak 4 kali. Parameter yang diukur yaitu: jumlah daun, panjang tanaman, dan berat akar. Hasil penelitian menunjukkan bahwa rataan jumlah daun berkisar antara 41,65 46,77 helai, panjang tanaman 35,97-36,67 cm, dan berat akar 1,95-1,72 g. Penggunaan urin sapi dengan konsentrasi berbeda dan lama perendaman tidak memberikan pengaruh yang nyata $(\mathrm{P}>0,05)$ terhadap jumlah daun, panjang tanaman, dan berat akar. Dapat disimpulkan bahwa konsentrasi urin dan lama perendaman tidak mempengaruhi jumlah daun, panjang tanaman, dan berat akar tanaman Arachis pintoi (A. pintoi).
\end{abstract}

Kata kunci: Konsentrasi Urin Sapi, Lama Perendaman, A. pintoi

\footnotetext{
ABSTRACT

INFLUENCE

$\mathrm{OF}$ CONCENTRATION AND SOAKING TIME OF $A$. pintoi IN THE COW URINE ON PLANT GROWTH. Cow urine has an auksin $a$, auksin b, and IAA (hetero auksin) that can

*Korespondensi (corresponding Author)

Email: novalia_L.gaol@yahoo.com
}

stimulate plant roots. The present study was conducted to determine the influence of concentration and soaking time in the cow urine on Arachis pintoi (A. pinto) growth. This study used Completely Randomized Design (CRD) in Factorial arrangement with 2 factors $\mathrm{A}$ and $\mathrm{B}$. Factor $\mathrm{A}=$ urine concentration: $\mathrm{A} 1=$ urine $75 \%$ + water $25 \%$ and $A 2$; urine $50 \%$ + water $50 \%$; and factor $\mathrm{B}=$ soaking time: $\mathrm{B} 1=$ 1 hour; B2 $=2$ hours; Dan, B3 $=3$ hours. Treatments were replicated 4 times. Parameters measured were: leaves amount (sheets), plant length $(\mathrm{cm})$, and root weight (g). Research results showed that mean leaves amount ranged from 41,65 to 46,77 sheets, plant length 35,97-36,67 cm, and root weight 1,95-1,72 g. Utilization of cow urine with a different concentration and soaking time gave a non significant different $(\mathrm{P}>0.05)$ on leaves amount, plant length, and root weight. It can be concluded that cow urine concentration and soaking time do not effect leaves amount, plant length, and root weight of Arachis pintoi (A. pinto).

Key words: Cow urine concentration, Soaking time, A. pintoi.

\section{PENDAHULUAN}

$$
\text { Ketersedian hijauan pakan }
$$

berkualitas sangat diperlukan terutama dalam pemeliharaan ternak ruminansia untuk diberikan dalam memenuhi kebutuhan pertumbuhannya. Salah satu tanaman pakan adalah A. pintoi 
merupakan salah satu jenis legum atau tanaman kacang-kacangan. Menurut sejarah, tanaman A. pintoi berasal dari Brazilia, yang memiliki karakteristik tahan injakan dan sering digunakan sebagai tanaman hias, penutup tanah, pakan ternak, dan pendukung kesuburan tanah. Pertumbuhan A. pintoi sangat pesat, karena dalam tiga bulan pertama telah mampu menutup $100 \%$ permukaan tanah dan menghasilkan biomassa yang tinggi, yakni 3,75 ton bobot kering/ ha/ tahun pada umur 14 minggu setelah tanam Erizal (2003). Arachis pintoi atau yang sering disebut dengan kacang hias juga merupakan salah satu tanaman penutup tanah yang dapat tumbuh dengan baik di daerah tropika, baik di dataran rendah maupun dataran tinggi Silmi dan Chozin (2014). Pertanaman A. pintoi mudah dikembangkan secara stek langsung dan mempunyai karakter pertumbuhan yang mampu menutup permukaan dengan sempurna. Keuntungan lain dari A. pintoi walaupun tumbuh menjalar di permukaan tanah namun tidak tumbuh memilin pada tanaman pokok. Tanaman penutup tanah juga efektif dalam memperbaiki sifat fisik tanah terutama struktur tanah dan memperkaya bahan-bahan organik tanah serta memperbesar porositas tanah, Baon dan Pudjiono (2006). Tanaman ini tahan terhadap kekeringan antara 3-4 bulan dan akan menggugurkan daunnya selama periode kering. Manfaat A. pintoi adalah untuk mencegah erosi tanah, mencegah pertumbuhan gulma dan sumber nitrogen bagi tanaman pokok. A. pintoi merupakan salah satu jenis hijauan leguminosa yang dapat dijadikan sebagai pakan karena memiliki nutrien tinggi. Berdasarkan analisa laboratorium Ciawi Bogor, kandungan nutriennya adalah : protein 17,06\%; serat kasar 17,96\%; lemak 3,54\%; BETN 53,43\% dan abu 8,01\% Rumambi (2012).

Di samping sebagai pakan, A. pintoi dapat digunakan sebagai cover crop pada tanaman kopi, pisang, kelapa sawit dan tomat serta efektif sebagai yaitu dengan menggunakan urin sapi untuk mendorong pertumbuhan akar, hal ini disebabkan karena di dalam urin diduga terdapat ZPT yang mempunyai efek seperti hormon auksin yang diperoleh dari hasil pakan yang dimakan oleh sapi, Pujawati (2009). Pengontrol nematode dan rumput liar pada tanaman kopi dan tomat. A. pintoi dapat dikembangkan di daerah dengan intensitas cahaya rendah karena tanaman ini toleran terhadap intensitas cahaya sedang dan sebagai tanaman penutup tanah yang pola penyebarannya horizontal, memiliki biomassa cukup tinggi yaitu berkisar antara 12-19 ton/ha / tahun bahan segar dan 3 - 6 ton/ha / tahun bahan kering. $A$. pintoi termasuk salah satu jenis legum yang memiliki banyak manfaat dalam 
bidang peternakan maupun pertanian. Manfaat lain dari tanaman ini dapat juga sebagai pengontrol erosi pada usaha tani lahan kering yang berlereng. Erosi terjadi terutama pada periode awal pertumbuhan tanaman yang menyebabkan lahan terdegradasi dan menurun produktivitasnya. A. pintoi dapat juga digunakan untuk makanan beberapa jenis ternak peliharaan seperti : sapi, kuda, keledai, biri-biri (domba), kambing, babi, dan ayam. Daunnya mengandung kadar protein antara 15,0-20,0 \% dan baik untuk pencernaan. Dalam upaya memenuhi kebutuhan ternak serta untuk meningkatkan pendapatan petani di daerah beriklim kering. Pengembangan A. pintoi merupakan salah satu alternatif yang dapat dipilih karena berdasarkan struktur akar tanamannya dapat membantu dalam pengambilan unsur-unsur hara.

Urin sapi adalah limbah yang berbentuk cairan atau berada dalam fase cair (air seni atau urin) dapat merangsang pertumbuhan akar karena mengandung auksin. Auksin merupakan salah satu zat pengatur tumbuh (ZPT) yang berperan penting pada proses pertumbuhan dan perkembangan suatu tanaman, Budianto E. A, dkk (2013). Auksin yang terdapat pada urin sapi adalah Auksin a (auxentriollic acid), auksin $\mathrm{b}$ (hetero auksin) dan indolylasetic acid (IAA). Urin adalah kotoran cair yang dikeluarkan dari tubuh sebagai senyawa buangan (limbah) sisa metabolisme tubuh Menurut Sosrosoedirdjo et al (1992). Kandungan urin sapi terdiri dari nitrogen $(\mathrm{N}) ; 1,4$ $2,2 \%$, fosfor $(\mathrm{P}) ; 0,6-0,7 \%$ dan kalium (K) 1,6-2,1\%. Pemanfaatan urin ternak sejak dulu telah digunakan oleh bangsa jepang untuk dijadikan pupuk. Berdasarkan kelebihan dari urin ternak sapi dan keunggulan $A$. pintoi di atas maka dilakukan penelitian untuk mengetahui pengaruh urin ternak sapi serta memperoleh data tentang konsentrasi dan lama perendaman pada urin sapi terhadap pertumbuhan A. pintoi.

\section{MATERI DAN METODE PENELITIAN}

\section{Tempat dan Waktu Penelitian}

Penelitian ini telah dilaksanakan di Lahan Agrostologi Fakultas Peternakan UNSRAT Manado. Penelitian ini berlangsung selama 40 hari pada tanggal 10 Mei 2016 s/d 10 Juni 2016.

\section{Materi Penelitian}

Bahan yang digunakan untuk penelitian ini adalah :
a) Stek tanaman A. Pintoi
b) Urine ternak sapi betina
c) Tanah

Alat -alat yang digunakan adalah : 

a) Polybag
b) Gelas ukur / Botol Aqua/ jergen
c) Timbangan
d) Penggaris,
e) Camera
f) Plang nama dan perlakuan
g) Tali plastik
h) Kalkulator
i) Kertas karton
j) Bambu
k) Paku
1) Martil
m) Plastik putih tebal.

\section{Rancangan Percobaan}

Penelitian ini menggunakan Rancangan Acak Lengkap Steel dan Torrie, (1995) dengan 2 pola faktorial, 3 perlakuan dengan 4 kali ulangan sehingga terdapat 24 satuan percobaan. Masingmasing perlakuan terdiri dari 2 faktor yaitu faktor A (urin $75 \%+25 \%$ air) dan (urin $50 \%+50 \%$ air) dengan faktor $\mathrm{B}$ lama perendaman dengan taraf $\mathrm{B}_{1}=1 \mathrm{jam}$ perendaman, $\mathrm{B}_{2}=2 \mathrm{Jam}$ perendaman, $\mathrm{B} 3=$ 3 Jam perendaman.

Model linier dari rancangan percobaaan faktorial dalam rancangan acak lengkap adalah:

$Y_{i j k}=\mu+A_{i}+B_{j}+(A B)_{i j}+G_{i j k}$

Keterangan :

$$
\begin{array}{ll}
\mathrm{Y}_{\mathrm{ijk}} & : \text { Pengamatan konsentrasi } \\
& \text { urine ke-i, perendaman ke-j, } \\
& \text { dan ulangan ke-k. } \\
\mu & \text { : Rataan umum } \\
\mathrm{A}_{\mathrm{i}} \quad \text { : Pengaruh konsentrasi urine } \\
\mathrm{ke-i} \\
\mathrm{B}_{\mathrm{j}} \quad \text { : Pengaruh perendaman urine } \\
\mathrm{ke-j}
\end{array}
$$

$(\mathrm{AB})_{\mathrm{ij}}$ : Interaksi konsentrasi urine ke-i dan perendaman ke-j

$\mathrm{G}_{\mathrm{ijk}}$ : Galat konsentrasi urine ke-i, perendaman ke-j dan ulangan ke-k.

Analisis : Uji Beda Nyata Jujur (BNJ) digunakan untuk melihat perbedaan antar perlakuan.

\section{Hipotesis}

$\mathrm{H}_{0}$ : Perlakuan konsentrasi dan lama perendaman pada urin ternak sapi memberikan pengaruh yang tidak nyata terhadap pertumbuhan A.pintoi

$\mathrm{H}_{1}$ : Perlakuan konsentrasi dan lama perendaman pada urin ternak sapi memberikan pengaruh yang nyata terhadap pertumbuhan A.pintoi.

Untuk kriteria pengambilan keputusan dari hipotesis yang diuji adalah :

F hitung $<\mathrm{F}$ tabel ; terima $\mathrm{H}_{0}$ 
$\mathrm{F}$ hitung $>\mathrm{F}$ tabel ; tolak $\mathrm{H}_{0}$

\section{Variabel Yang Diukur}

1. Jumlah Daun

Jumlah helai daun yang diamati adalah jumlah daun yang muncul pada tanaman selama pengamatan. Pengamatan jumlah daun dilakukan dengan cara menghitung jumlah daun yang telah membuka sempurna tiap 7 hari hingga panen sesudah tanaman berumur 20 hari.

2. Panjang Tanaman

Diukur mulai pangkal batang tegak lurus dari permukaan tanah sampai daun tertinggi, daun ditarik keatas mengikuti panjang tanaman.

3. Berat Akar

Berat akar di timbang setelah penghitungan jumlah daun dan panjang tanaman A pintoi.

\section{Prosedur Penelitian}

a. Persiapan Tempat dan Media Tanah

Tempat yang digunakan adalah sabua yang terbuat dari bambu dengan penutup menggunakan plastik putih transparan pada luas $2,5 \times 2,5 \mathrm{~m}$ serta tinggi sabua $3 \mathrm{~m}$. Tanah yang digunakan terlebih dahulu dibersihkan dengan menggunakan ayakan tanah agar supaya tidak tercampur dengan batu-batu kecil. Tanah dimasukkan ke dalam polybag yang berukuran $15 \times 15$ kemudian ditimbang dengan berat yang sama yaitu $3 \mathrm{~kg} /$ poliback.

b. Penyediaan Stek

Bahan stek diambil dari taman Fakultas Kedokteran jurusan keperawatan unsrat Manado. Adapun kriteria pengambilannya adalah stek berukuran 5-7 $\mathrm{cm}$ dipotong dengan menggunakan kater. Pengambilan stek dilihat dari bentuk batang serta ukurannya, jika batang berwarna hijau kecoklatan maka dapat di jadikan stek untuk ditanam. Stek yang diambil berjumlah sekitar 72 , stek yang digunakan dalam penelitian ini adalah stek pucuk.

c. Perlakuan dengan Urine Sapi

Sebelum ditanam stek di rendam pada urin sapi dengan konsentrasi yang berbeda. Pada perlakuan perendaman di mulai pada jam 3 sore. Perlakuan perendaman yang pertama adalah 3 jam dengan konsentrasi $75 \%$ urin $+25 \%$ air dan $50 \%$ urin $+50 \%$ air. Jumlah urin $75 \%$ dan $50 \%$ masingmasing dikurangi dari 1 liter jumlah urin ternak. Setiap selisih waktu satu jam, kemudian dilanjut ke perlakuan yang 2 jam kemudian dikutkan dengan perlakuan yang 1 jam.

d. Penanaman

Sebelum stek ditanam terlebih dahulu ditiriskan kemudian ditanam pada polybag dengan kedalam $3 \mathrm{~cm}$ kemudian tanah dipadatkan mengelilingi stek agar 
stek tidak miring menghadap ke bawah tanah.

e. Pemeliharaan

1. Penyiraman dilakukan pada hari ketiga setelah tanam, kemudian untuk penyiraman selanjutnya pada stek dilakukan dengan melihat kelembaban pada tanaman karena jika terlalu banyak air disiram pada tanaman stek dapat mengakibatkan pembusukan pada stek.

2. Penyiangan dilakukan setiap minggu dengan mencabut gulma yang tumbuh pada media polybag jika ada agar tidak terjadi persaingan terutama dalam memperoleh air oleh tanaman.

HASIL DAN PEMBAHASAN

Jumlah Konsentrasi Urine dan Lama Perendaman Terhadap Jumlah Daun
Pengaruh perlakuan konsentrasi dan lama perendaman terhadap jumlah daun dapat dilihat pada Tabel 1. Variabel pengamatan jumlah daun sangat diperlukan sebagai indikator pertumbuhan dan sebagai penunjang untuk menjelaskan proses pertumbuhan yang terjadi seperti pembentukan biomassa pada tanaman.

Dari hasil analisis keragaman Tabel 1. menunjukkan bahwa perlakuan penggunaan urin dengan konsentrasi yang berbeda dan lama perendaman tidak memberikan pengaruh yang nyata $(\mathrm{P}>0,05)$ terhadap jumlah daun, tetapi pada gambar histogram terlihat bahwa jumlah daun pada perlakuan A2B1, A2B2, A2B3 memberikan hasil yang lebih baik dibandingkan dengan jumlah daun pada A1B1, A1B2, A1B3. Hal ini mungkin disebabkan oleh perendaman yang terlalu lama, sehingga menyebabkan mulai terjadinya proses pembusukan pada tanaman seperti yang telah dilakukan

Tabel 1. Rataan Pengaruh Konsentrasi Urin dan Lama Perendaman Terhadap Jumlah Daun (Helai) A .pintoi.

\begin{tabular}{lllll}
\hline Perlakuan & B1 & B2 & B3 & Rataan \\
\hline A1 & 43,15 & 41,5 & 40,325 & 41,65 \\
A2 & 55,87 & 45,05 & 39,4 & 46,77 \\
\hline Total & 49,51 & 43,27 & 39,86 & \\
\hline
\end{tabular}

Ket : Tabel di atas menunjukkan perbedaan yang tidak nyata pada jumlah daun $(\mathrm{P}>0,05)$. 
pra penelitian sebelumnya bahwa pada batang tanaman A.pintoi mulai terjadinya pembusukan dan ditandai dengan warna kehitaman pada batang. Perendaman dengan konsentrasi yang rendah pada waktu 1 jam ada kemungkinan memberikan hasil yang lebih baik dari pada lama perendaman 2 jam dan 3 jam.

Unsur N (nitrogen) merupakan unsur hara di dalam tanah yang sangat berperan bagi pertumbuhan tanaman. Unsur nitrogen (N) juga berfungsi untuk merangsang pertumbuhan tanaman secara keseluruhan, terutama batang, cabang, dan daun. Selain unsur N, bahan organik juga membantu menyediakan unsur P (fosfor). Unsur $P$ sangat penting sebagai menetralkan proses metabolisme atau katalisator sumber energi. Unsur $\mathrm{K}$ (kalium) berperan penting dalam pembentukan antibodi tanaman untuk melawan penyakit. Urine ternak sapi memiliki pengaruh yang baik pada perbaikan pertumbuhan terutama pada jumlah daun pada konsentrasi urin $50 \%$ dengan lama perendaman $1 \mathrm{jam}$. Menurut pendapat Pujiwati (2009) menyatakan bahwa, urine sapi dapat digunakan sebagai sumber auksin. Air kemih ini harus diencerkan dengan air bersih sehingga diperoleh konsentrasi 5 - $10 \%$. Pencelupan dilakukan selama 10 - 15 detik menjelang ditanam.

\section{Perlakuan Jumlah Konsentrasi Urine dan Lama Perendaman Terhadap Panjang Tanaman}

Pengaruh konsentrasi dan lama perendaman urin sapi terhadap panjang tanaman A.pintoi dapat di lihat pada Tabel 2. Pertumbuhan tanaman ditunjukkan dengan penambahan ukuran bobot kering yang mencerminkan bertambahnya protoplasma karena ukuran maupun jumlah sel bertambah dan pemberian auksin dapat memacu perpanjangan sel sehingga dapat meningkatkan pertumbuhan batang.

Tabel 2. Rataan Panjang Tanaman $(\mathrm{Cm})$ pada Perendaman Urine dengan Konsentrasi yang Berbeda.

\begin{tabular}{lccccc}
\hline & Perlakuan & B1 & B2 & B3 & Rataan \\
\hline & A1 & 12,4 & 12,225 & 12,05 & 36,675 \\
& A2 & 13,875 & 11,725 & 10,375 & 35,975 \\
\hline Total & & 26,275 & 23,95 & 22,425 & \\
\hline Ket $:$ Tabe di atas & & & \\
\hline
\end{tabular}

Ket : Tabel di atas menunjukkan perbedaan yang tidak nyata pada panjang tanaman A.pintoi $(\mathrm{P}>0,05)$. 
Dari hasil analisis keragaman Tabel 2. menunjukkan bahwa perlakuan penggunaan urin dengan konsentrasi yang berbeda dan lama perendaman tidak memberikan pengaruh yang nyata $(\mathrm{P}>0,05)$ terhadap jumlah daun, tetapi pada gambar histogram terlihat bahwa jumlah daun pada perlakuan A2B1, A2B2, A2B3 memberikan hasil yang lebih baik dibandingkan dengan jumlah daun pada A1B1, A1B2, A1B3. Hal ini mungkin disebabkan oleh perendaman yang terlalu lama, sehingga menyebabkan mulai terjadinya proses pembusukan pada tanaman A.pintoi sedangkan perendaman dengan konsentrasi yang rendah pada waktu 1 jam ada kecenderungan memberikan hasil yang lebih baik. Hal ini dapat dipengaruhi oleh berbagai faktor seperti Faktor dalam (internal factor) yaitu faktor tanaman itu sendiri/sifat yang terdapat dalam tanaman tersebut kemudian Faktor lingkungan (environmental factors). Faktor dalam yang mempengaruhi yaitu macam dan umur bahan stek, adanya tunas dan daun, kandungan bahan makanan, kandungan zat pengantur tumbuh dan terbentuknya kalus. Sedangkan fakto luar adalah media perakaran, kelembaba, suhu, cahaya dan faktor lingkungan sangat mempengaruhi pertumbuhan tanaman Suprapto (2004). A. pintoi tumbuh subur di bawah naungan namun pertumbuhannya lebih baik yang ditanam di tempat terbuka yang mendapatkan sinar matahari yang tinggi. Pertumbuhan juga dapat ditunjukkan oleh adanya pertambahan ukuran dan berat kering yang tidak dapat balik akibat bertambahnya protoplasma, ukuran sel maupun jumlahnya Baon dan Pudjiono (2006).

Tabel 3. Rataan Berat Akar (gram) pada Perendaman Urine dengan Konsentrasi yang Berbeda.

\begin{tabular}{ccccc}
\hline Perlakuan & B1 & B2 & B3 & Rataan \\
\hline A1 & 0,6825 & 0,53 & 0,5125 & 1,725 \\
A2 & 0,7075 & 0,6875 & 0,56 & 1,955 \\
\hline Total & 1,39 & 1,2175 & 1,0725 & 3,68
\end{tabular}

Ket : Tabel di atas menunjukkan perbedaan yang tidak nyata pada berat akar A.pintoi ( $>>0,05)$. 
Jumlah Konsentrasi Urine dan Lama Perendaman Terhadap Berat Akar

Pengaruh konsentrasi dan lama perendaman pada urin ternak sapi terhadap berat akar tanaman A.pintoi dapat dilihat pada Tabel 3. Penyerapan unsur hara dan air oleh akar sangat menentukan pertumbuhan tanaman baik pada bagian tanaman yang berada di permukaan atas maupun di dalam tanah. Tanaman yang tumbuh dalam keadaan kurang air membentuk akar lebih banyak dengan hasil yang lebih rendah dibandingkan dengan tanaman yang tumbuh dalam keadaan cukup air Sari (2009).

Kurangnya ketersediaan unsur hara pada tanaman akan mempengaruhi pada pertumbuhan tanaman tersebut. Pertumbuhan awal terbentuknya akar dimulai oleh adanya metabolisme cadangan nutrisi yang berupa karbohidrat yang menghasilkan energi yang selanjutnya mendorong pembelahan sel dan membentuk sel-sel baru dalam jaringan Kastono dan Siswandono (2005). Auksin sangat diperlukan dalam pembentukan akar yakni memacu terjadinya pembelahan sel. Penggunaan auksin diketahui dapat mengintensifkan proses pembentukan akar pada stek. Menurut Fanesa (2011) pemberian urine sapi dapat memberikan pengaruh pada pertumbuhan akar tanaman karena auksin alami yang terkandung dalam urine sapi 25 \% dapat mendorong perakaran setek. Struktur tanah yang dikehendaki tanaman adalah struktur tanah yang gembur yang di dalamnya terdapat ruang pori - pori yang dapat diisi oleh air dan udara yang amat penting bagi pertumbuhan akar tanaman Sari, (2009).

\section{KESIMPULAN}

Berdasarkan hasil penelitian dapat disimpulkan bahwa konsentrasi urin dan lama perendaman tidak menunjukkan perbedaan yang nyata akan tetapi ada kemungkinan bahwa perendaman 1 jam dengan konsentrasi urin 50\% masih jauh lebih baik terhadap jumlah daun, panjang tanaman, dan berat akar.

\section{DAFTAR PUSTAKA}

Baon J. B dan H. Pudjiono. 2006. Intensitas penutup tanah arachis pintoi dan inokulasi rhizobium serta penambahan fosfor dan pengaruhnya terhadap pertumbuhan tanaman kakao dan status hara di lapangan. Pelita Perkebunan 22(2): 76-90

Budianto. E. A., K. Badami, A. Arsyadmunir. 2013. Pengaruh kombinasi macam ZPT dengan lama perendaman yang berbeda terhadap keberhasilan pembibitan sirih merah (Piper crocatum ruiz \& pav) secara stek. Agrovigor 6(2): 103-11.1 
Erizal, 2003. Aplikasi Teknologi Irigasi Sprinkler dan Drip. Lembaga Penelitian IPB. Bogor.

Fanesa A. 2011. Pengaruh Pemberian Beberapa Zat Pengatur Tumbuh Terhadap Pertumbuhan Setek Pucuk Jeruk Kacang (citrusnobilis 1). Skripsi. Fakultas Pertanian Universitas Andalas, Padang.

Kastono, D., H. Sawitri dan Siswandono. 2005. Pengaruh nomor ruas stek dan dosis pupuk urea terhadap pertumbuhan dan hasil kumis kucing. Jurnal Ilmu Pertanian. 12(1): 56-64.

Silmi. F. dan M.A. Chozin. 2014. Pemanfaatan biomulsa kacang hias (arachis pintoi) pada budidaya jagung manis (zea mays saccharata sturt.) di lahan kering. J. Hort. Indonesia 5(1):1-9.

Pujiwati . E. D. 2009. Pertumbuhan stek jeruk lemon ( citrus medica) dengan pemberian urin sapi pada berbagai konsentrasi dan lama perendaman. Jurnal Hutan Tropis Borneo, 10 (26) : 201-209.
Rumambi A. 2012. Penyediaan pakan berkelanjutan melalui inokulasi fungi mikoriza arbuskula dan aplikasi fosfat alam pada arachis pintoi $\mathrm{cv}$ amarillo dalam tumpang sari dengan jagung (Zea mays. L) atau sorgum (sorghum bicolor 1, moench). Disertasi. Fakultas Peternakan, IPB, Bogor.

Sari. M. P, 2009. Pengaruh Lama Perendaman Dalam Urin Sapi dan Dosis Pupuk Kandang Sapi Terhadap Pertumbuhan Setek Nilam (Pogostemon cablin, Benth). Skripsi. Fakultas Pertanian, Universitas Sebelas Maret, Surakarta

Suprapto, A. 2004. Auksin: Zat pengatur tumbuh penting meningkatkan mutu setek tanaman. J. Penelitian 21(1): 81-90.

Suprijadji, G. dan A.A. Prawoto. 1992. Kandungan hormon dalam air seni beberapa jenis ternak. Pusat Penelitian Perkebunan Jember. Pelita Perkebunan. 7(4):79-84.

Steel, R.G.D dan J. H. Torrie 1992. Prinsip dan Prosedur Statistik, Gramedia. Pustaka Utama, Jakarta. 